\title{
Juror and community views of the guilty plea sentencing discount: Findings from a national Australian study
}

\author{
Kate Warner \\ University of Tasmania, Australia \\ kate.warner@utas.edu.au; ph: 6136226 2067; fax: +61 362267623
}

Kate Warner is an Emeritus Professor at the University of Tasmania. Her principal research interest is in sentencing law and procedure, in which she has continued her research since her appointment as Governor of Tasmania in December 2014. ORCID: https://orcid.org/0000-0001-7483-5420

Caroline Spiranovic

University of Tasmania, Australia

caroline.spiranovic@utas.edu.au; ph: +61 362264847

Caroline Spiranovic has a $\mathrm{PhD}$ in Psychology and works predominantly in multi-disciplinary teams on criminology, law and forensic psychology research projects focusing on crime prevention, public opinion and risk assessment. ORCID: https://orcid.org/0000-0002-5270-8719

Lorana Bartels

Australian National University, Canberra

lorana.bartels@anu.edu.au; ph:+61261251279

Lorana Bartels is Program Leader of Criminology at the Australian National University and Adjunct Professor of Law at the University of Canberra and University of Tasmania. Her research interests are sentencing, corrections and the treatment of women and Indigenous peoples in the criminal justice system. ORCID: https://orcid.org/0000-0002-2037-884X

\section{Lynne Roberts}

Curtin University, Western Australia

lynne.roberts@curtin.edu.au; ph: + 61089266 7183; fax: + 61892662464

Lynne Roberts is an Associate Professor in the School of Psychology at Curtin University in Perth, Western Australia. She conducts research at the intersection of psychology and criminology, with a focus on public attitudes towards crime and justice. She has co-authored more than 150 peer-reviewed publications. ORCID: https://orcid.org/0000-0003-0085-9213

\section{Karen Gelb \\ University of Melbourne, Victoria, Australia \\ drkarengelb@gmail.com; ph: +61 414680645}

Karen Gelb is a consultant criminologist and a lecturer in the Department of Criminology at the University of Melbourne, Australia. She has researched and written extensively on a range of criminal justice issues, including public opinion about crime and justice, courts, family violence, young offenders, sex offenders and drugs. ORCID: https://orcid.org/0000-0002-9114-125X

\section{Corresponding author:}

Lorana Bartels, College of Arts and Social Sciences, Australian National University, Canberra ACT 2601 Australia.

Email: lorana.bartels@anu.edu.au 


\begin{abstract}
A plea of guilty is a long-accepted factor mitigating sentence in many countries, including Australia, although academic debate over the merits and application of the discount is ongoing. This paper presents findings from a national Australian study on public opinion on the guilty plea sentencing discount, with a particular focus on sexual offences. Survey data was drawn from 989 jurors in cases that resulted in a guilty verdict and 450 unempanelled jurors and 306 online respondents who were provided with vignettes based on real cases. A third of respondents would have supported a discount in their case if the offender had pleaded guilty. In contrast, more than one half of respondents surveyed, who had received a vignette with a guilty plea scenario, supported an increment in sentence if the offender had gone to trial. There was more support for a discount in cases involving non-sexual violent offences versus sexual offences and adult versus child victims. Where a discount was supported, this most commonly was a reduction in the length of custodial sentence, with online respondents allocating the least generous discounts. Willingness to accept a sentencing discount was predicted by a range of variables including gender, education, punitive attitudes, offence type and offence seriousness. We conclude by considering the implications of our findings for sentencing law and practice.
\end{abstract}

\title{
Keywords
}

Sentencing and public opinion, guilty plea discount, sex offence sentencing 


\section{Introduction}

This paper examines Australian public attitudes to the guilty plea sentencing discount. A plea of guilty is a long-accepted factor mitigating sentence in Australia, New Zealand, England and Wales, Scotland, Canada and the United States (US). All Australian jurisdictions except Tasmania have legislative provisions which require a sentencing court to take into account the fact that an offender has pleaded guilty. In England and Wales, there is a guideline for sentence reductions for a guilty plea (Sentencing Council for England and Wales (Sentencing Council), 2017). Guilty plea discounts (regardless of whether the plea is motivated by remorse) are commonly justified on the benefits that flow from providing an incentive to plead guilty (Freiberg, 2014; Leverick, 2014).

While it is not always mandatory to award a sentencing discount for a guilty plea, it is almost invariably the practice to do so and, in many jurisdictions, the judge may or must state the amount of the discount if awarded. In some jurisdictions, there is also a formal legislative or guideline scale for discounts, based on timing of the plea. In a study of guilty plea cases in the Crown Court in England and Wales in 2011-2012, a sentence reduction was awarded in all but $3 \%$ of cases, with the most frequently awarded reduction being one-third of the sentence (Roberts and Bradford, 2015). In the Australian state of Victoria, research on pleas of guilty in the higher courts over a five-year period found that a guilty plea was 'almost always viewed as a mitigating factor' and the most common discount for imprisonment sentences was 20-30\% (Victorian Sentencing Advisory Council (VSAC), 2015: 59-60). A study in the Australian Capital Territory (ACT) of Supreme Court sentencing decisions between January 2011 and June 2013 revealed a discount in all cases where the offender pleaded guilty, with an average reduction of 22\% (Wren and Bartels, 2014).

Despite broad acceptance by courts and governments of a plea of guilty as a mitigating factor, academic debate over the merits of the discount is ongoing. Objections to the guilty plea discount have targeted a range of issues, including that it can induce an innocent person to plead guilty; it is unfair to, in effect, penalise those who elect to go to trial when it is a fundamental human right to have the prosecution's case proved beyond reasonable doubt; it is unacceptable for a sentence that is considered by the judge to be appropriate to the gravity of the crime and circumstances of the offender to be reduced on the basis of something unrelated to the offending; awarding a discount does not directly address the problem of delays; and there is insufficient empirical evidence of its effectiveness in producing guilty pleas. On the other hand, arguments in favour of the discount include reductions in court delays, which may give rise to injustice and reduced costs, as well as removing the need for victims to give evidence in sensitive cases (Ashworth, 2015; Bagaric, Edney and Alexander. 2019; Dershowitz, 2019; Mack and Roach Anleu, 1997; Mackenzie, 2007; Wren and Bartels, 2014).

Even if it is accepted that a discount is appropriate, there is debate about its application: whether the motivation for the plea (subjective vs utilitarian) is relevant; the factors to be taken into account in determining the discount, such as the type and seriousness of the offence; the appropriate size of the discount; and whether the discount amount should be discretionary or fixed by a scale (Tasmanian Sentencing Advisory Council (TSAC), 2018; Leverick, 2014). These are also issues that governments and law reform bodies have grappled with when they have tried to develop a statutory scheme. For example, South Australia offered a generous $40 \%$ for a very early plea (putting the utilitarian value first), but this has been controversial, especially for serious offending and has been reconsidered (Martin, 
2019). By contrast, most Australian jurisdictions, led by New South Wales, have chosen $25 \%$ as the maximum discount (see Wren and Bartels, 2014).

Concern that sentences imposed by the courts are too lenient is a constant refrain in the media. A mismatch between factors that the courts consider to be relevant to sentence and those which the public feels should be relevant is likely to contribute to dissatisfaction with sentencing. Public opinion research shows that the guilty plea discount is one area where the law and lay views are misaligned. A recent report prepared for the Sentencing Council found that only $55 \%$ of respondents felt that a guilty plea should be taken into account at sentencing (Marsh et al, 2019). An earlier study for the Sentencing Council focusing entirely on attitudes to guilty plea discounts found only $21 \%$ of respondents favoured reductions in all or most cases and 29\% were of the view it should never result in a reduction (Dawes et al, 2011). A study for the Scottish Sentencing Council, which explored public attitudes to various sentencing factors, found that only $26 \%$ of respondents felt that a guilty plea should result in a more lenient sentence (Black et al, 2019).

The guilty plea study for the Sentencing Council found that there were differences in public attitudes depending on the type of crime: while $22 \%$ of the general public considered that there should be no sentence reduction for a guilty plea in a case of serious fraud, $30 \%$ held this view for a case of serious assault and $43 \%$ in a case of rape (Dawes et al, 2011). Another interesting finding from this study was that focus group participants were uncomfortable with the language and discourse of reductions. They were resistant to the idea of rewards for admitting guilt and more comfortable with a penalty for pleading not guilty if defendants were convicted (Dawes et al, 2011, 5). Women in this study were more resistant than men to guilty plea reductions with a third (35\%) saying it should never result in a more lenient sentence compared with a quarter of men (23\%) (Dawes et al, 2011, 17). A different question about the size of plea-based discounts revealed that $70 \%$ of respondents favoured a reduction of less than one-third (Dawes et al, 2011, 25) .

It is well-known that providing the public with more information about specific cases improves people's confidence in the fairness of the criminal justice system and elicits less punitive responses (Cullen et al, 2000; Gelb, 2006; Roberts and Hough, 2005; Varma and Marinos, 2013; Warner et al, 2017). However, providing research participants with sufficient information to elicit truly informed opinion can be challenging. Using jurors from trials with guilty verdicts is one way of ensuring that respondents are well-informed about the facts of the case. Having sat through a trial themselves, jurors are also well aware of the burden on victims and witnesses of a trial and of the time taken to process a case through the criminal justice system.

As discussed further below, this article draws on data from a multi-stage national Australian jury study on sex offence sentencing. This study aimed to explore community attitudes to sentencing in sex and other (non-sexual) violent offences, by comparing three groups: empanelled jurors following their handing down of a guilty verdict; members of the public who had been called up for jury duty but not selected on a trial; and an online sample of members of the public. Earlier studies have shown that while, in general, jurors suggested a more lenient sentence than the judge had imposed, this was not the case for sexual offences and for child sexual offences in particular (Warner et al, 2017). For this reason, the national study focused on sexual offences, to explore why sex offences attract a more punitive response from jurors, compared with violent offences and focus on aggravating and mitigating factors particularly relevant to sex offences. With the inclusion of vignettes, the 
national study provided scope to include questions in relation to the relevance of plea to sentence. This article reports on findings from the first stage of the study relating to the guilty plea discount.

In light of the foregoing review of the literature, we posited a number of avenues of enquiry in relation to guilty pleas. First, given that jurors had just experienced a trial, we hypothesised that they would be more likely to support a sentencing discount for a guilty plea than other members of the public (non-jurors). Whether they would be more likely to accept such a discount in sex offence cases than violent offence cases was more difficult to predict. In Dawes et al's 2011 study, there was less support for a sentencing discount in cases of rape than serious assault. However, jurors may be more appreciative than non-jurors of the ordeal of a trial for sex offence victims and therefore more inclined to support a discount in such cases, on the grounds that the victim has been relieved of the burden of giving evidence. On the other hand, the public tends to be more punitive in relation to sex offences, especially child sex offences, than other offences (VSAC, 2011; Warner et al, 2017). This suggests that non-jurors would be less likely to recommend a discount in cases of sex offences than violent offences and least likely to do so in cases of child sexual assault. In addition, Dawes et al's (2011) finding that members of the public were more comfortable with the concept of penalty increases for not guilty pleas than reductions for guilty pleas prompted an exploration of the question of whether respondents would be more likely to endorse a penalty increase for a not guilty plea than a reduction for a guilty plea. Finally, Dawes et al's (2011) findings suggested that gender, education and offence type are associated with willingness to accept a sentencing discount but this study presented an opportunity to build on the knowledge base by exploring the relative important of a range of seemingly pertinent variables in predicting willingness to support a sentencing discount. On the basis of the broader literature on predictors of attitudes to sentencing (Gelb, 2011; King and Maruna, 2009; Spiranovic et al, 2012), as well as studies on public attitudes to guilty plea discounts (i.e. Dawes et al., 2011), it was expected that support for a guilty plea discount would be predicted by the respondents' demographic factors, levels of punitiveness and the nature of the offence.

The following questions are addressed in this article:

1. Did jurors feel that the sentence for the offender they had tried should have been reduced if the offender had pleaded guilty?

2. Were jurors, with the experience of a real trial, more likely to favour a sentencing discount than non-jurors?

3. Were non-jurors more likely to approve a sentencing increase for a not-guilty plea than a reduction for a guilty plea? ${ }^{1}$

4. If a discount was considered appropriate, what was the nature and size of the discount?

5. Did responses differ for sex and violent offences and across different kinds of sex offence (e.g. adult victims and child victims)?

6. Besides offence type, did offence seriousness, other demographic factors (e.g. age, education, gender) or punitive attitudes predict acceptance of a guilty plea discount? 
The article aims to consider the implications of the findings for sentencing practice, including whether or not it would be appropriate to respond to any mismatch between the law's approach to guilty plea discounts and public views by changing the law.

\section{Method}

The method for this study builds on previous jury sentencing research in Australia (see Spiranovic et al, under review; Warner and Davis, 2012; Warner et al, 2017), but sought to canvass the views of jurors as well as non-jurors across all of Australia's eight states and territories.

Between 2014 and 2016, we recruited 989 jurors in 128 sex and 31 other violent offence trials in each of the Australian states and territories except Western Australia, where we were unable to gain the Attorney-General's approval to conduct the study. After the guilty verdict, but before sentence, jurors were asked to select the sentence they thought should be imposed on the offender. They were then asked: 'If the defendant had pleaded guilty in this case, avoiding the need for a trial, would you have imposed a shorter or more lenient sentence?' If they responded 'Yes', they were asked to state their preferred sentence. The survey also explored respondents' views about the purpose of their selected sentence, general views about current sentencing practice, beliefs about those who commit sex and other violent offences and questions to explore confidence and punitiveness. This was the first of three surveys and the only one which is of relevance to the issue of sentencing discount for guilty pleas. The paper-based survey was either completed at the court or taken away and mailed by the juror to the investigators. In the majority of cases, surveys were completed at the court. In South Australia, the surveys were distributed to jurors by mail at the end of each court sitting to comply with the Court's conditions of approval reducing the response rate from that jurisdiction (just $2.3 \%$ of our sample of jurors and 3.6\% of unempanelled jurors came from South Australia).

There were two comparison groups of non-jurors. Group $1(\mathrm{n}=450)$ consisted of members of the public who had responded to the notice to attend for jury service, but were not subsequently selected to serve on a jury ('unempanelled jurors'). If they agreed to participate, they were given a survey which began with a description of one of ten possible vignettes.

Nine of these were sex offence scenarios and one was a violent offence. Three involved pleas of guilty (all sex offences). The questions which followed the vignette mirrored those in the jurors' survey, except that the question about a guilty plea was altered for the three vignettes with a guilty plea to read: 'If the defendant had pleaded not guilty which meant that the case had to go to trial would you have imposed a longer or more severe sentence?'

Group 2 ( $n=306)$ consisted of an online survey of Western Australian community members. While not part of the original research plan, this was added because we were unable to secure approval from the Western Australian Attorney-General to survey either jurors or unempanelled jurors. The online respondents were recruited through quota sampling of a Qualtrics panel, with participants receiving a small amount of monetary compensation from Qualtrics for completion of the survey. The online surveys replicated those used for the unempanelled jurors, with the addition of some questions relating to the Blackstone ratio (see Roberts et al, under review). 


\section{Variables}

The key dependent variable used in this study measured people's willingness to accept a discount for a guilty plea for the case heard/vignette assigned $(0=$ no; $1=y e s)$. Three sets of independent variables were included:

- Demographic variables: age as a continuous variable, gender $(0=$ male; $1=$ female $)$ and education $(0=$ diploma, trade certificate or no tertiary education; $1=$ undergraduate or post-graduate education).

- Perceptions of sentencing as a measure of punitiveness: perceptions of leniency in sentencing for sex offence cases $(0=$ less punitive - perceptions that sentences are 'much too tough', 'a little too tough' or 'about right'; $1=$ more punitive - perceptions that sentences are 'a little too lenient' or 'much too lenient').

- Offence characteristics: an objective measure of offence type $(0=$ violent/non-sex offence; $1=$ sex offence) and a judicial measure of offence seriousness, represented by the length of the prison term imposed ( $0=$ less than five years; $1=$ five years or more). The offence seriousness variable excluded less than $5 \%$ of cases where a noncustodial sentence was imposed.

\section{Results}

As set out above, surveys were received from 989 jurors, 450 unempanelled jurors and 306 online Western Australian respondents. While jurors were recruited from all jurisdictions except Western Australia and unempanelled jurors from all jurisdictions except Western Australia and NSW, the majority of respondents (57.8\%) were from Victoria, where a combination of the number of trials and the assistance of the Juries Commissioner and his staff meant that recruitment of respondents was particularly successful.

\section{To what extent did jurors and non-jurors support a guilty plea discount?}

More than a third of respondents (34.2\%) would have favoured giving a sentencing discount to the offender if they had entered a plea of guilty. This was highest for jurors $(36.5 \%$ of $n=$ $914)$, while unempanelled jurors $(32.0 \%$ of $n=303)$ were slightly less likely to accept a reduction in sentence for a guilty plea and only one-quarter of the online community sample $(24.7 \%$ of $n=150)$ did so.

Pairwise comparisons of these differences between groups using the Chi-square statistic indicated that the only significant difference was between jurors and the online sample $\left(\chi^{2}(1\right.$, $1207)=8.002, p=.005 ; \mathrm{phi}=.087)$. Accordingly, jurors were significantly more likely than the online sample to accept a reduction in sentence had the offender pleaded guilty, although the magnitude of this association is small.

To what extent did non-jurors in guilty plea scenarios support increasing the sentence if the offender had gone to trial? And were they more likely to do so than support a reduction for a guilty plea?

As explained above, three of the scenarios presented to the non-jurors were guilty pleas and seven were not guilty pleas. Rather than being asked about the sentence if the offender had 
pleaded guilty, the non-jurors in guilty plea scenarios were asked about the sentence if the offender had gone to trial. Over one-half of non-jurors who had read a scenario with a guilty plea (52.5\% of the unempanelled sample and $54.5 \%$ of the online sample) favoured increasing the sentence had the offender pleaded not guilty, with no significant difference between the two groups.

Chi-square tests revealed statistically significant differences in the proportion of respondents willing to change their sentence (either increasing the sentence for a not guilty plea or decreasing the sentence for a guilty plea), based on whether they had seen a scenario in which the defendant pleaded not guilty or guilty (see Table 1).

Table 1: Proportion of respondents willing to change sentence

\begin{tabular}{|l|c|cc|}
\hline \multicolumn{1}{|c|}{$\begin{array}{c}\text { All non-jurors } \\
\text { (unempanelled+online) } \\
(\mathbf{N}=\mathbf{7 5 6})\end{array}$} & $\begin{array}{c}\text { Unempanelled } \\
\text { jurors only } \\
(\mathbf{N}=\mathbf{4 5 0})\end{array}$ & $\begin{array}{c}\text { Online sample only } \\
(\mathbf{N}=\mathbf{3 0 6})\end{array}$ \\
\hline $\begin{array}{l}\text { Not guilty } \\
\text { scenario }\end{array}$ & $30.5 \%$ & $32.0 \%$ & $28.4 \%$ \\
\hline Guilty scenario & $53.1 \%$ & $52.0 \%$ & $54.5 \%$ \\
\hline & $\begin{array}{c}\chi^{2}(1,756)=32.912, \\
p<.001 ; \mathrm{phi}=.212\end{array}$ & $\begin{array}{c}\chi^{2}(1,450)=15.027, \\
p<.001 ; \mathrm{phi}=.187\end{array}$ & $\begin{array}{c}\chi^{2}(1,306)=18.555, \\
p<.001 ; \mathrm{phi}=.246\end{array}$ \\
\hline
\end{tabular}

These analyses show that non-jurors were significantly more likely to approve a sentence increase for a not-guilty plea than a sentence reduction for a guilty plea.

\section{If a discount was supported, what was the nature and size of the discount?}

Jurors and non-jurors from not guilty scenarios who agreed they would have imposed a more lenient sentence were asked what that sentence would be. Analysing responses required a comparison with each respondent's original suggested sentence. To code the comparison, variables were constructed for: reductions in length of suggested prison sentence; shifts from prison to home detention; shifts from custodial to non-custodial sentences; reduction in the duration of non-custodial sentence; and shifts to a more lenient non-custodial sentence.

For all three samples, the most common type of discount was a reduction in the length of the custodial sentence (see Table 2). Among jurors, $87.4 \%$ would have reduced the sentence in this way, most commonly by reducing the custodial term by half (see Table 3 ). Among the unempanelled jurors, $86.2 \%$ would have reduced the custodial term, again mostly by half. For the online sample, $97.1 \%$ would have reduced the custodial term, most commonly by onequarter. 
Table 2: Type of discount chosen if the offender had pleaded guilty

\begin{tabular}{|lccc|}
\hline & $\begin{array}{c}\text { Jurors } \\
(\mathbf{n = 2 0 6 )}\end{array}$ & $\begin{array}{c}\text { Unempanelled } \\
(\mathbf{n = 8 7})\end{array}$ & $\begin{array}{c}\text { Online } \\
(\mathbf{n}=\mathbf{3 4 )}\end{array}$ \\
\hline Reduce custodial sentence length & $87.4 \%$ & $86.2 \%$ & $97.1 \%$ \\
\hline Shift from prison to home detention & $1.5 \%$ & $2.3 \%$ & $0.0 \%$ \\
\hline Shift from custodial to non-custodial & $5.3 \%$ & $4.6 \%$ & $0.0 \%$ \\
\hline Reduce non-custodial sentence length & $2.9 \%$ & $6.9 \%$ & $2.9 \%$ \\
\hline $\begin{array}{l}\text { Shift to more lenient non-custodial } \\
\text { sentence }\end{array}$ & $1.9 \%$ & $0.0 \%$ & $0.0 \%$ \\
\hline Minor adjustment & $1.0 \%$ & $0.0 \%$ & $0.0 \%$ \\
\hline
\end{tabular}

Table 3: Amount of discount chosen if the offender had pleaded guilty

\begin{tabular}{|lccc|} 
& $\begin{array}{c}\text { Jurors } \\
(\mathbf{n = 1 7 3})\end{array}$ & $\begin{array}{c}\text { Unempanelled } \\
(\mathbf{n = 7 1 )}\end{array}$ & $\begin{array}{c}\text { Online } \\
(\mathbf{n}=\mathbf{3 1})\end{array}$ \\
\hline $\mathbf{2 0} \%$ & $4.0 \%$ & $14.1 \%$ & $16.1 \%$ \\
\hline $\mathbf{2 5 \%}$ & $8.7 \%$ & $11.3 \%$ & $22.6 \%$ \\
\hline $\mathbf{3 0 \%}$ & $5.2 \%$ & $1.4 \%$ & $3.2 \%$ \\
\hline $\mathbf{3 3 \%}$ & $9.2 \%$ & $8.5 \%$ & $19.4 \%$ \\
\hline $\mathbf{4 0} \%$ & $16.8 \%$ & $11.3 \%$ & $9.7 \%$ \\
\hline $\mathbf{5 0 \%}$ & $20.8 \%$ & $19.7 \%$ & $3.2 \%$ \\
\hline $\mathbf{6 0} \%$ & $4.0 \%$ & $1.4 \%$ & $0.0 \%$ \\
\hline $\mathbf{6 7 \%}$ & $4.0 \%$ & $2.8 \%$ & $0.0 \%$ \\
\hline Other $^{2}$ & $27.2 \%$ & $29.6 \%$ & $25.8 \%$ \\
\hline
\end{tabular}

While all three groups were most likely to reduce the length of the custodial sentence had the offender pleaded guilty, jurors and unempanelled jurors were more likely than the online sample to consider other options as a sentence discount. The online sample was also less generous with the amount of discount that would be applied.

\section{Was there a difference between offence types?}

Figure 1 shows that jurors and unempanelled jurors were less likely to reduce the sentence for a guilty plea in sex cases than other violent offences. The results for the online sample are reversed, but this difference was not statistically significant. All three cohorts were less likely to reduce the sentence in sex cases involving a child, rather than an adult. 
Figure 1: Proportion of respondents accepting a sentence reduction for a guilty plea, by offence type and victim age

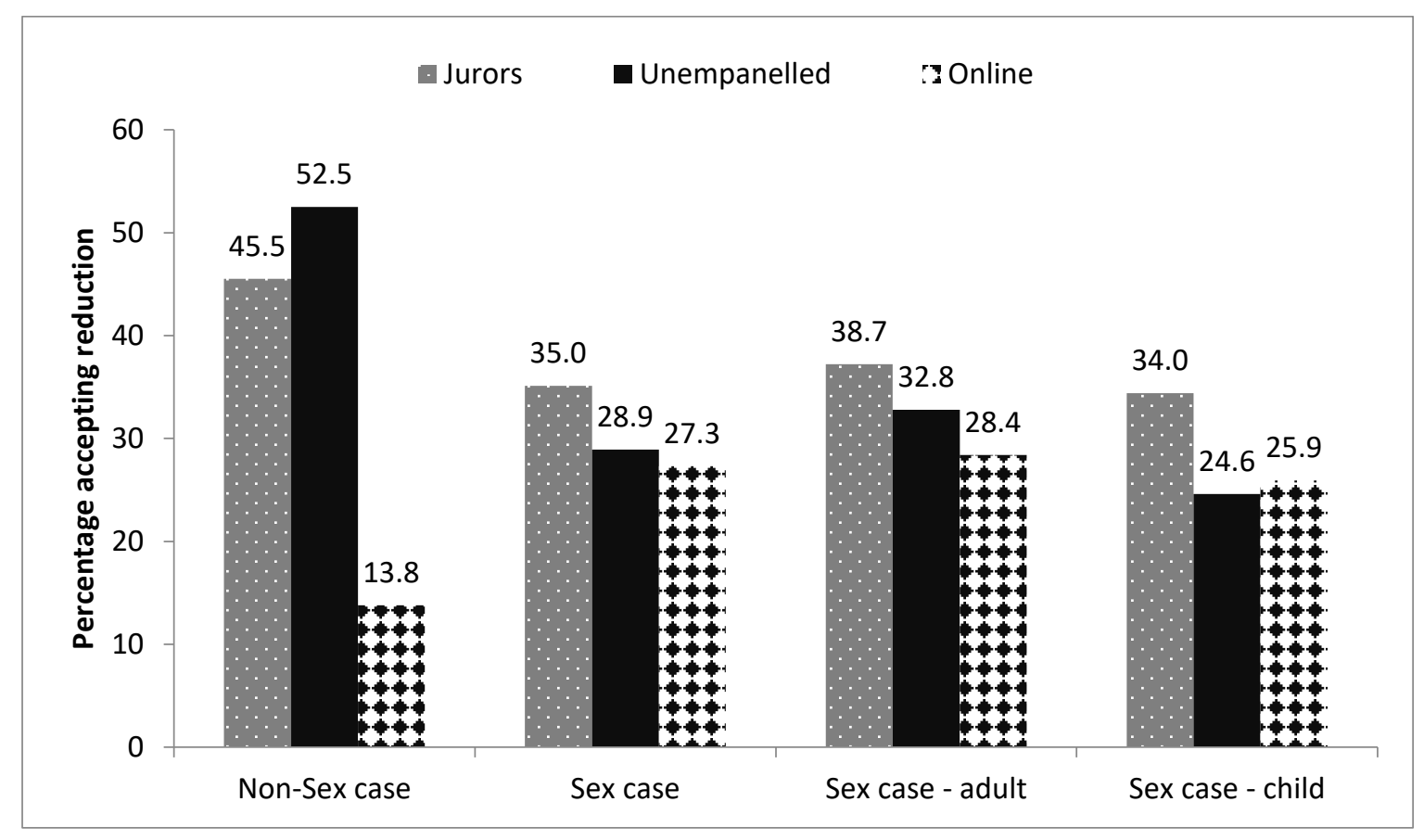

Notes:

1. Numbers varied according to group: $\mathrm{N}=989$ jurors, $\mathrm{N}=320$ unempanelled and $\mathrm{N}=218$ online.

2. Of 989 jurors, 154 heard a violent offence trial and 835 heard a sex offence trial.

3. Of 320 unempanelled jurors, 44 read a violent offence scenario and 276 read a sex offence scenario. Of 218 online respondents, 29 read a violent offence scenario and 189 read a sex offence scenario.

Chi-square tests revealed statistically significant differences in the proportion of respondents willing to accept a sentence reduction had the defendant pleaded guilty based on the nature of the case. For jurors, there was a statistically significant difference in the proportion willing to reduce their sentence based on the offence type: $45.5 \%$ would reduce the sentence for a violent crime but only $35.0 \%$ would do so for a sex offence $\left(\chi^{2}(1,989)=5.460, p=.019\right.$; phi=.077). For unempanelled jurors as well, there was a statistically significant difference in willingness to reduce the sentence: $52.5 \%$ would reduce the sentence for a violent crime but only $28.9 \%$ would do so for a sex offence $\left(\chi^{2}(1,320)=8.887, p=.003 ;\right.$ phi $\left.=.171\right)$. There were no significant differences found among the online sample, possibly due to the smaller sample size.

There were no statistically significant differences for any of the groups in willingness to accept a sentence reduction for a guilty plea based on the age of the victim. It thus appears that offence type - whether the offence is a sex offence - is associated with the likelihood of accepting a sentence discount for a guilty plea, while the age of the victim is not. The role of offence type in predicting acceptance of discounts for guilty pleas is further explored below.

\section{What predicts support for a sentence discount for a guilty plea?}

In order to identify predictors of support for a sentence discount for a guilty plea, three separate logistic regressions were conducted, for jurors, unempanelled jurors who had 
received a scenario involving a plea of not guilty and people in the online sample who had received a scenario with a not guilty plea. Adding all of these variables into a logistic regression model provides an estimate of the relative and unique statistical importance of each of these variables once other variables in the model have been taken into account. Logistic regression may therefore be more informative than analysing individual associations between each variable and willingness to accept a discount, as each individual association may appear significant but the unique statistical contribution of each variable may be less when other variables are taken into consideration in the one analysis. To identify the separate impact of each kind of predictor, a hierarchical logistic regression with three levels was conducted. Model 1 included the demographic variables only, Model 2 added the measure of punitiveness and Model 3 added the two offence characteristic measures.

Table 4 presents the parameters of the model at each step of the regression for each of the three cohorts, using the first category of the independent variable (i.e. no support for discount) as the reference category.

Table 4: Parameter estimates for variables predicting acceptance of a sentence discount for a guilty plea

\begin{tabular}{|c|c|c|c|c|c|c|}
\hline & & $\begin{array}{l}\text { rors } \\
=989 \text { ) }\end{array}$ & Unempa & $\begin{array}{l}\text { led jurors } \\
\text { 20) }\end{array}$ & On & $\begin{array}{l}\text { sample } \\
\text { 218) }\end{array}$ \\
\hline & B & $\begin{array}{c}\operatorname{Exp}(\mathrm{B}) \\
{[\mathrm{LCI}, \mathrm{HCI}]}\end{array}$ & B & $\begin{array}{c}\operatorname{Exp}(\mathrm{B}) \\
{[\mathrm{LCI}, \mathrm{HCI}]}\end{array}$ & B & $\begin{array}{c}\operatorname{Exp}(\mathrm{B}) \\
{[\mathrm{LCI}, \mathrm{HCI}]}\end{array}$ \\
\hline & & & Model 1 & & & \\
\hline Age & $.01 *$ & $\begin{array}{c}1.01 \\
{[1.00-1.02]}\end{array}$ & -.00 & $\begin{array}{c}1.00 \\
{[.98-1.02]}\end{array}$ & .01 & $\begin{array}{c}1.01 \\
{[.98-1.04]}\end{array}$ \\
\hline Gender $^{a}$ & $-.45 * *$ & $\begin{array}{c}.64 \\
{[.47-.87]}\end{array}$ & $-.91 * * *$ & $\begin{array}{c}.40 \\
{[.24-.67]}\end{array}$ & -.95 & $\begin{array}{c}.39 \\
{[.15-1.00]}\end{array}$ \\
\hline Education $^{b}$ & $.38 *$ & $\begin{array}{c}1.46 \\
{[1.08-1.98]}\end{array}$ & .22 & $\begin{array}{c}1.25 \\
{[.73-2.14]}\end{array}$ & $1.06 *$ & $\begin{array}{c}2.90 \\
{[1.18-7.13]}\end{array}$ \\
\hline & & & Model 2 & & & \\
\hline Age & $.01^{*}$ & $\begin{array}{c}1.01 \\
{[1.00-1.02]}\end{array}$ & -.01 & $\begin{array}{c}1.00 \\
{[.98-1.02]}\end{array}$ & .00 & $\begin{array}{c}1.00 \\
{[.97-1.04]}\end{array}$ \\
\hline Gender & $-.40^{*}$ & $\begin{array}{c}.67 \\
{[.49-.92]}\end{array}$ & $-.87 * * *$ & $\begin{array}{c}.42 \\
{[.25-.71]}\end{array}$ & $-1.00 *$ & $\begin{array}{c}.37 \\
{[.14-.97]}\end{array}$ \\
\hline Education & $.33 *$ & $\begin{array}{c}1.39 \\
{[1.02-1.89]}\end{array}$ & .16 & $\begin{array}{c}1.18 \\
{[.68-2.03]}\end{array}$ & $1.21 *$ & $\begin{array}{c}3.36 \\
{[1.32-8.51]}\end{array}$ \\
\hline Punitiveness ${ }^{c}$ & $-.43 *$ & $\begin{array}{c}.65 \\
{[.45-.94]}\end{array}$ & -.49 & $\begin{array}{c}.62 \\
{[.31-1.21]}\end{array}$ & 1.10 & $\begin{array}{c}3.00 \\
{[.50-17.9]}\end{array}$ \\
\hline & & & Model 3 & & & \\
\hline Age & $.01 *$ & $\begin{array}{c}1.01 \\
{[1.00-1.02]}\end{array}$ & -.01 & $\begin{array}{c}1.00 \\
{[.98-1.01]}\end{array}$ & .00 & $\begin{array}{c}1.00 \\
{[.97-1.04]}\end{array}$ \\
\hline Gender & $-.41 * *$ & $\begin{array}{c}.66 \\
{[.48-.91]}\end{array}$ & $-.90 * * *$ & $\begin{array}{c}.41 \\
{[.24-.70]}\end{array}$ & $-1.01 *$ & $\begin{array}{c}.37 \\
{[.14-.99]}\end{array}$ \\
\hline Education & $.33 *$ & $\begin{array}{c}1.39 \\
{[1.02-1.90]}\end{array}$ & .07 & $\begin{array}{c}1.07 \\
{[.61-1.87]}\end{array}$ & $1.13 *$ & $\begin{array}{c}3.09 \\
{[1.19-8.03]}\end{array}$ \\
\hline Punitiveness & $-.47 *$ & $\begin{array}{c}.63 \\
{[.43-.90]}\end{array}$ & -.45 & $\begin{array}{c}.64 \\
{[.32-1.27]}\end{array}$ & 1.34 & $\begin{array}{c}3.81 \\
{[.58-25.16]}\end{array}$ \\
\hline Offence type ${ }^{\mathrm{d}}$ & $-.54^{*}$ & $\begin{array}{c}.58 \\
{[.37-.92]}\end{array}$ & $-1.18 * *$ & $\begin{array}{c}.31 \\
{[.14-.67]}\end{array}$ & .75 & $\begin{array}{c}2.11 \\
{[.77-5.80]}\end{array}$ \\
\hline
\end{tabular}




\begin{tabular}{|c|c|c|c|c|c|c|}
\hline $\begin{array}{l}\text { Offence } \\
\text { seriousness }\end{array}$ & $.33 *$ & $\begin{array}{c}1.40 \\
{[1.00-1.95]}\end{array}$ & -.48 & $\begin{array}{c}.62 \\
{[.34-1.13]}\end{array}$ & 1.22 & $\begin{array}{c}3.38 \\
{[.78-14.58]}\end{array}$ \\
\hline \multicolumn{7}{|l|}{ Notes: } \\
\hline${ }^{\mathrm{a}}$ Gender; $0=\mathrm{m}$ & & \multicolumn{5}{|c|}{${ }^{\mathrm{b}}$ Education; $0=$ less than undergraduate } \\
\hline${ }^{\mathrm{c}}$ Punitiveness; & nu & \multicolumn{5}{|c|}{${ }^{\mathrm{d}}$ Offence type; $0=$ non-sex offence } \\
\hline
\end{tabular}

Jurors

For jurors, the overall model only accounted for a small proportion of the variance in support for a guilty plea sentence discount (Nagelkerke $\left.R^{2}=.06\right) .^{3}$

Model 3 shows that all the variables were statistically significant predictors (although for some, such as age, the effect is trivial). ${ }^{4}$ The strongest predictor of support for a sentence discount in this sample was offence type, with a $42 \%$ reduction in the odds of accepting a discount for sex, versus other violent, offences. Offence seriousness was almost as strong a predictor, with a $40 \%$ increase in the odds of accepting a discount for offences attracting a longer prison sentence than a shorter term.

The strongest demographic predictor for jurors was education, with a higher education increasing the likelihood of sentence discount acceptance by $39 \%$. Gender was also a strong predictor: women were $34 \%$ less likely to support a discount than men.

There was a significant difference in the likelihood of supporting a sentence discount for a guilty plea based on levels of punitiveness, with a $37 \%$ reduction in the odds of accepting a discount among people who were more punitive.

\section{Unempanelled jurors}

For the unempanelled jurors who received a not-guilty scenario, the overall model only accounted for around one-tenth of the variance in support for a guilty plea sentence discount (Nagelkerke $\left.R^{2}=.12\right)^{5}$

Model 3 shows that the strongest predictor of support for a sentence discount was offence type: there was a $69 \%$ reduction in the likelihood of accepting a sentence discount for a guilty plea for a sex offence scenario when compared with a non-sex offence scenario. The likelihood of supporting a sentence discount for a guilty plea was also significantly lower among women than among men, with a 59\% reduction in the odds for women. No other factors were statistically significant in the model for unempanelled jurors.

\section{Online sample}

For members of the online sample who received a not-guilty scenario, the overall model accounted for one-fifth of the variance in support for a guilty plea sentence discount (Nagelkerke $\left.R^{2}=.21\right)^{6}$

Model 3 shows that only education and gender were significant for this sample: there was a large increase (by a factor of three) in the likelihood of accepting a discount among those with higher levels of education and a $63 \%$ reduction for women in the odds of accepting a sentence discount for a guilty plea, but only once punitiveness levels were statistically controlled for. The wide confidence intervals around significant effects for this group reduce the confidence we can have in these findings, indicating the need for replication. 


\section{Discussion}

\section{Minority support only for a guilty plea discount}

There was only minority support for a guilty plea discount, ranging from $24.5 \%$ in the online sample to $36.5 \%$ among jurors. It seems that the argument that it is inappropriate to reduce a sentence on the basis of facts unrelated to offence seriousness or the offender's level of culpability is one that is likely to resonate with many members of the public. This finding is broadly in line with other public opinion research demonstrating an absence of broad support for guilty plea discounts (Black et al, 2019; Dawes et al, 2011; Marsh et al, 2019).

Despite differences in the questions in the UK studies and the fact respondents in our study were asked about a discount in relation to one specific offence, the findings are consistent in showing considerable public resistance to a sentence reduction for a guilty plea. The following community submission to the recent review of the South Australian guilty plea sentencing reduction scheme is illustrative of public disquiet with discounts in that state:

No reductions should be allowed for pleas of guilty. The legal system is not a supermarket. Offenders must be held accountable. ... Large reductions in cases of serious crime are out of touch with community opinions and expectations (Martin, $2019,[43])$.

\section{Jurors were more supportive of a discount than the online sample}

Jurors who have sat through a sex or violent offence trial would be particularly aware of the victim's ordeal of reliving the offence through giving evidence and would be more alert to the impact of preparing for and running a trial than other members of the public. For jurors, the concept of a guilty plea discount is likely to be less abstract. In the Sentencing Council's study of attitudes to guilty plea sentence reductions, it was found that victim and witness reactions to reductions were 'more positive than the general public' (Dawes et al 2011, 18). For these reasons, we anticipated that jurors would be more supportive of the discount than non-jurors. This was borne out by the results, although the difference between jurors $(36.5 \%)$ and unempanelled jurors (32\%) was not significant. However, it should be noted that this is not a clear comparison of like cases with like, with the only difference being the plea. The juror sample had 153 different cases, while the non-jurors had just seven different scenarios involving a not-guilty plea. Constructing a study comparing jurors in real cases with nonjurors using the same cases would be very difficult, but could reveal greater differences. Despite the shortcomings of the comparison, it does support the well-established finding from public opinion sentencing research that providing more information yields different and generally more lenient responses.

\section{There is resistance to the language and discourse of reductions for guilty pleas}

The finding that non-jurors who had a guilty plea scenario were significantly more likely to support an increment for pleading not guilty than non-jurors with a not guilty plea scenario were to support a discount for pleading guilty aligns with Dawes et al's $(2011,5)$ finding that the language of reductions for guilty pleas did not 'sit well' with the public, who were more comfortable with a penalty for not admitting guilt. It seems that increasing a penalty for a reason unrelated to offender culpability or offence seriousness is much more palatable than 
reducing it for such a reason. While this finding reinforces the public discomfort with guilty plea discounts, it also shows that many members of the public are prepared to take into account factors unrelated to offender culpability or offence seriousness in assessing sentences, at least when it comes to increasing it.

\section{When discounts were accepted, they tended to be quite generous}

The number of valid responses to the question about the size of the discount was small particularly for the unempanelled jurors $(n=71 / 450)$ and online respondents $(n=31 / 306)$ but also for jurors $(n=173 / 989)$, partly because only a minority agreed to a discount, but also because of missing or unquantifiable responses. Nevertheless, the finding that the most common sentencing reduction by empanelled and unempanelled jurors was a reduction in the length of the custodial sentence of one-half is surprisingly generous. The online sample result of a quarter of the custodial sentence is more in line with sentencing practice.

Suggested discounts were also more generous than those in the Sentencing Council's study, where the most common response to a question on appropriate levels of sentence reduction, was 'about $10 \%$ ' (29\% of respondents) followed by 'about a quarter' (Dawes et al 2011, 25). It is plausible that the contrasting results are due to the different styles of each question calculating the difference in suggested sentence in our question compared with a predetermined list of seven possible responses from 'no reduction' to 'more than half' in the Sentencing Council study. Nevertheless, our findings suggest that, if a discount is accepted as appropriate, it can be a significant one.

\section{Both empanelled and unempanelled jurors were more likely to support a discount for violent offences than sex offences}

It could be argued that the utilitarian value of the guilty plea is greatest in the case of sex offences, as victims' experience of giving evidence and undergoing cross-examination tends to be more traumatic than for other offences. Children in particular tend to be more vulnerable witnesses than adults. However, this was not reflected in jurors' increased willingness to accept a discount. Instead, they were significantly less likely to do so in the case of sex offenders and, in such cases, also less likely to suggest a discount if the victim was a child, although this difference was not significant. The likelihood of accepting a guilty plea discount was significantly lower for a sex offence case among both jurors and unempanelled jurors. However, the differences across sex and violent offences was not significant for the online sample. It is unclear why the results were different for the online sample, but it is likely to be due to a combination of small numbers and the different methodology used for these participants.

Dawes et al (2011) also found less acceptance of guilty plea discounts in sex offence cases. The survey results using brief vignettes of serious fraud, serious assault and rape found the public was less accepting of guilty plea discounts in the case of rape than serious assault and more accepting of a discount in the case of serious fraud. It appears that, despite the increased utilitarian value of guilty pleas in sex offence cases, the public is less willing to reduce a sentence that reflects the gravity of the crime for this type of offence.

It is noteworthy that there is greater resistance to plea-based sentencing discounts in sex cases. Lenient sentences for these offences are particularly likely to generate public and 
media criticism, which in turn tends to undermine community confidence in sentencing. At the same time, the value for victims and witnesses in avoiding the delays and trauma of a trial is most easily seen in the context of sex offence trials. There is potential for the utilitarian value of the plea and the incentives the discount provides to offenders to admit guilt to be clearly explained and better understood by members of the public to help allay concerns that discounts generate. There is a clear role for government here, as well as courts, although we acknowledge the political tension here between the common 'tough on sex offenders' rhetoric and the legislative provisions in relation to guilty pleas discounts.

\section{Gender, education level and punitiveness predicted level of support for the sentencing discount}

Gender was a strong predictor of support for a sentencing discount for a guilty plea, with women less likely than men to support it in both the empanelled juror and unempanelled juror groups. This was also the case in Dawes et al's (2011) study, which reported that women were particularly resistant to a sentencing discount for a guilty plea. Dawes et al also found that those educated at least to degree level were more supportive of discounts than other respondents. For jurors in our study, respondents' level of education also predicted support for a discount. This finding aligns with broader public opinion research on punitiveness lower levels of education have consistently predicted punitive attitudes in Australia (Gelb, 2011; Spiranovic et al, 2012) and England (King and Maruna, 2009).

An expected finding was that jurors who were more punitive were less likely to support a sentencing discount for a guilty plea.

\section{Jurors convicting an offender of a more serious offence were more likely to suggest a sentencing discount}

Australian law recognises that 'for particularly serious offences', the gravity of the offence is a factor relevant to the discount provided (TSAC, 2018, 66; Bagaric, Edney and Alexander, 2019) and evidence shows judges in Victoria tend to give smaller discounts for more serious offences (VSAC, 2015). Moreover, qualitative findings from discussion groups and interviews in England and Wales show more acceptance of sentence reductions for minor crimes (Dawes et al, 2011). However, Leverick (2014) argues that offence seriousness is not a principled basis for reducing a discount, which should instead be decided on grounds relevant to the benefits of guilty pleas. In light of this debate about whether the seriousness and type of offence should be relevant to determining a guilty plea discount, offence seriousness was included in the regression analysis. The finding that jurors from trials with more serious offences (attracting sentences of five or more years' imprisonment) were more likely to suggest a discount than those from trials resulting in shorter sentences, independently of crime type, was perhaps surprising. While this finding does not support Leverick's position, which is against giving courts the discretion to consider offence seriousness in considering the discount, the fact that jurors were more prepared to countenance a discount in more serious cases - and that, if a discount was recommended, it was sizeable - does not fit well with the Australian approach that the seriousness of the offence can justify a reduction in the discount. 


\section{Conclusion}

The Australian jury sex offence sentencing study provided a unique opportunity to explore the reaction of jurors in a real trial to the idea of a guilty plea discount, a sentencing practice shared by many jurisdictions around the world, including all common law jurisdictions. The findings are of relevance to the ongoing debate about guilty plea discounts and the factors relevant to the discount. The finding that there was only minority support for guilty plea discounts, even among jurors and particularly in sex offence cases, confirms that guilty plea discounts are a potential source of dissatisfaction with sentencing.

What are the implications of the mismatch between limited public support for the guilty plea discount and sentencing practice? Public dissatisfaction with the discount could be seized upon as reason for abolishing it as a 'tough on crime' or 'truth in sentencing' measure, with the argument that sentences should not be reduced based upon facts which are unrelated to offence seriousness. Moreover, the law's position that that allowing a reduction for a guilty plea does not involve penalising an accused for going to trial and that pleading not guilty is a neutral, rather than aggravating factor is unconvincing. The limited public support for the discount also suggests that care is needed when increases in the magnitude of the discount are being considered, as sizeable discounts could lead to a decline in public confidence in the criminal justice system and a punitive backlash.

However, abandoning the sentencing discount should be strongly resisted. Longer sentences would be inevitable, leading to increases in the imprisonment rate, with no advantage in terms of a reduction in crime and disadvantages in terms of both financial and broader social costs (see Bartels, 2017). Moreover, with no incentive for defendants to plead guilty, it is likely that delays in the criminal justice system would be exacerbated and many more stakeholders in a case would suffer the stress of a trial, with the potential for retraumatisation particularly high for victims of sexual offences.

Could public dissatisfaction with guilty plea discounts be addressed by changing the terminology, namely abolishing the discount, but adding a premium for pleading not guilty? In theory this is possible but such a measure is likely to meet with strong opposition. It blatantly flouts the presumption of innocence, from which it should follow that an accused person is entitled to require the prosecution to prove her or his guilt without being penalised for doing so. Theoretically, it may be possible to recalibrate sentences, so that the change did not result in an increase in sentence severity (as was attempted with the abolition of remissions in Victoria: see Freiberg and Ross, 1999). However, the change remains a populist and punitive response, which fails to acknowledge that, while there are risks associated with guilty plea discounts, there are also public benefits which need to be balanced.

Rather than replacing the guilty plea discount with a not guilty plea premium, it would be better to ensure that the community benefits of guilty pleas, particularly reducing the emotional stress to victims, are better understood by the general public. That the public may be receptive to this is indicated by the fact that jurors, with their fresh experience of a trial and some appreciation of what it involves, were more likely than other members of the public to (a) suggest a guilty plea discount and (b) do so even in more serious cases. Moreover, their discounts were considerably more generous than the online sample. It is here that Australia's sentencing councils and governments could be mobilised to work towards increasing community understanding of the benefits of guilty pleas. At the same time, judges themselves could contribute to improved public understanding through the publication of 
accessible, clear and explicit remarks that both quantify any sentencing discount and also directly explain the benefits of guilty pleas to victims and the administration of justice.

\section{Acknowledgments}

We wish to acknowledge the valuable input and involvement of other Chief Investigators, namely Prof Geraldine Mackenzie, Dr David Plater and Prof George Zdenkowski, in the earlier stages of this project. We are also greatly indebted to our Partner Investigators from the Department of Justice, Tasmania; Victorian Sentencing Advisory Council; Australasian Institute of Judicial Administration; and the ACT Victims of Crime Commissioner. This study would not have been possible though without the generous support of state and territory courts, judges and Attorneys-General who were willing to participate in this research by granting us access to their jury pool members or otherwise assisting us with undertaking this work. We would like to extend a special thanks to the Victorian Juries Commissioner and his staff, who went above and beyond what we would have hoped for in supporting this project.

\section{Declaration of Conflicting Interest}

The authors declared no potential conflicts of interest with respect to the research, authorship and publication of this article.

\section{Funding}

The authors disclosed receipt of the following financial support for the research, authorship and/or publication of this article: The project was funded by an Australian Research Council Linkage Grant, Project ID: LP 130100083 with the following partners: Department of Justice, Tasmania; VSAC; Australasian Institute of Judicial Administration; and the ACT Victims of Crime Commissioner. This project also received internal funding from the Australian

National University and University of South Australia.

\section{Notes}

1. Non-jurors had either guilty plea or not guilty plea scenarios, but jurors necessarily had only not guilty pleas trials.

2. 'Other' discount amounts ranged from $9 \%$ to $96 \%$; most of these include only one or two respondents.

3. The overall correct classification rate for the full model was $61.8 \%$, with the percentage of correct classifications at $88.8 \%$ for the absence of support for a sentence discount, but only $17.5 \%$ for the presence of support for a guilty plea discount. The overall correct classification rate relates to the overall percentage of cases that were correctly predicted by the logistic regression model.

4. The significance of age may be due solely to the large sample size.

5. The overall correct classification rate for the full model was $70.2 \%$, with the percentage of correct classifications at $93.9 \%$ for the absence of support for a sentence discount, but only $23.9 \%$ for the presence of support for a guilty plea discount.

6. The overall correct classification rate for the full model was $72.6 \%$, with the percentage of correct classifications at $93.3 \%$ for the absence of support for a sentence discount, but only $22.6 \%$ for the presence of support for a guilty plea discount. 


\section{References}

Ashworth A (2015) Sentencing and Criminal Justice, $6^{\text {th }}$ ed. Cambridge University Press.

Bagaric M, Edney R and Alexander T (2019) Sentencing in Australia, $7^{\text {th }}$ ed. Sydney: Lawbook Co.

Bartels L (2017) Criminal justice law reform challenges for the future: It's time to curb Australia's prison addiction. In: Levy R et al (eds.), New Directions for Law in Australia. Canberra: Australian National University Press, 119-132.

Black C, Warren R, Ormston R and Tata C (2019) Public Perceptions of Sentencing, National survey report, Submitted to the Scottish Sentencing Council.

Cullen FT, Fisher BS and Applegate BK (2000) Public opinion about punishment and corrections. In: Tonry M (ed.) Crime and Justice: A Review of the Research, Volume 27. Chicago, IL: University of Chicago Press, 1-79.

Dawes W, Harvey P, McIntosh B, Nunney F and Phillips A (2011) Attitudes to guilty plea sentence reductions, Sentencing Council Research Series 02/11.

Dershowitz AM (2019) Most Plea Bargains are Unconstitutional. Wall Street Journal 8 November.

Freiberg A (2014) Fox and Freiberg's Sentencing: State and Federal Law in Victoria, $3^{\text {rd }}$ ed. Sydney: Lawbook Co.

Freiberg A and Ross S (1999) Sentencing Reform and Penal Change: the Victorian Experience. Sydney: The Federation Press.

Gelb K (2006) Myths and misconceptions: Public opinion versus public judgment about sentencing. Melbourne: VSAC.

Gelb K (2011) Predictors of punitiveness: Community views in Victoria. Melbourne: VSAC.

Leverick F (2014) Sentencing Discounting for Guilty Pleas: An Argument for Certainty over Discretion. Criminal Law Review 338-349.

Mack K and Roach Anleu S (1997) Sentencing Discount for a Guilty Plea: Time for a New Look. Flinders Law Journal 1: 123- 143.

Mackenzie G (2007) The Guilty Plea Discount: Does Pragmatism Win Over Proportionality and Principle. Southern Cross University Law Review 11: 205-223.

Martin BR (2019) Review of the Sentence Reduction Scheme of the Sentencing Act 2017 (SA), Interim Report to the Attorney-General.

Marsh N, McKay E, Pelly C and Cereda S (2019) Public Knowledge of and Confidence in the Criminal Justice System and Sentencing - A Report for the Sentencing Council. 
Maruna S and King A (2009) Once a Criminal, Always a Criminal?: Redeemability and the Psychology of Punitive Public Attitudes. European Journal on Criminal Policy and Research 15: 7-24.

Roberts L, Lipscombe T, Spiranovic C, Warner K, Bartels L, Gelb K and Davis J (under review) Public Attitudes Toward Conviction for Sex Offences: Does Blackstone's Ratio have Any Relevance in Australia? Australian and New Zealand Journal of Criminology.

Roberts JV and Hough M (2005) Understanding Public Attitudes to Criminal Justice. Maidenhead UK: Open University Press.

Roberts JV and Bradford B (2015) Sentencing Reductions for a Guilty Plea in England and Wales: Exploring New Empirical Trends. Journal of Empirical Legal Studies 12: 187-210.

Sentencing Council for England and Wales (2017) Reduction in sentence for a guilty plea: Definitive guideline.

Spiranovic C, Warner K, Bartels L, Roberts L, Gelb K, and Davis J (under review). National Study of Juror Views on Sentencing Sex Crimes in Australia. Punishment and Society.

TSAC (2018) Statutory Sentencing Reductions for Pleas of Guilty, Final Report No 10.

Varma, KN and Marinos V (2013) Three decades of public attitudes research on crime and punishment in Canada. Canadian Journal of Criminology and Criminal Justice 55: 549-562.

VSAC (2015), Guilty Pleas in the Higher Courts: Rates, Timing and Discounts.

Warner K and Davis J (2012) Using jurors to explore public attitudes to sentencing. British Journal of Criminology 52(1), 93-112.

Warner K, Davis J, Spiranovic C, Cockburn H and Freiberg A (2017) Measuring jurors' views on sentencing: Results from the second Australian jury sentencing study. Punishment \& Society 19: 18-202.

Wren E and Bartels L (2014) 'Guilty Your Honour': Recent legislative developments on the guilty plea discount and an Australian Capital Territory case study on its application. Adelaide Law Review 35: 361-384. 